To cite: NC Ani 'Implications of the African Union's stance on immunity for leaders on conflict resolution in Africa: The case of South Sudan and lessons from the Habré case' (2018) 18 African Human Rights Law Journal 438-462

\title{
Implications of the African Union's stance on immunity for leaders on conflict resolution in Africa: The case of South Sudan and lessons from the Habré case
}

\author{
Ndubisi Christian Ani* \\ Researcher, Institute for Security Studies, Addis Ababa, Ethiopia
}

\section{Summary}

After 2009 when the International Criminal Court issued an arrest warrant against President Omar Al Bashir of Sudan, the African Union began to promote an immunity principle for sitting leaders and senior government officials. The immunity principle was formalised in article 46 Abis of the Protocol on Amendments to the Protocol on the Statute of the African Court of Justice and Human Rights. While the immunity principle raised an uproar among civil society groups, there has been limited scholarly engagement with its implications for conflict resolution and the need to deter would-be perpetrators of international crimes. Thus, the article examines the impact of the AU's immunity principle on conflict resolution efforts in Africa using South Sudan as a case study and drawing lessons from the case involving the former President of Chad, Hissène Habré. The article contends that even though an AU-led hybrid court without any immunity provisions is to be established in South Sudan, the $A U$ 's historical immunity stance will impede the hybrid court from trying the warring leaders who are the main actors responsible for the crimes in South Sudan. As such, the immunity principle provides opportunities for the warring leaders, who eventually will be leaders and senior government officials in line with the peace deal, to enjoy impunity for international crimes. If it is established the court most likely will focus on trying scapegoats of the warring factions in a tokenist effort at justice. The Habré case reveals that the trial of incumbent leaders is possible when incumbent leaders lose political power, but prosecution depends on additional variables such as a lack of international support. In the context

* PhD (KwaZulu-Natal); christian-ani@outlook.com 
of the proclivity of some leaders on the continent to remain in power beyond their constitutional mandates, the AU's immunity stance further provides an incentive for the 'sit-tight-in office syndrome' to avoid future probes into international crimes. The article argues that the AU's strategic shift away from the immunity stance could prevent impunity and provide leaders with greater legitimacy.

Key words: African Court; African Union; International Criminal Court; South Sudan; Hissène Habré; human rights; conflict resolution

\section{Introduction}

This article examines the positive stance of the African Union (AU) on immunity for leaders and senior government officials and its impact on conflict resolution and justice in Africa. The article uses South Sudan as a case study and explores lessons from the Hissène Habré case. It is premised on article 46Abis of the Protocol on Amendments to the Protocol on the Statute of the African Court of Justice and Human Rights (Amendment Protocol) that was adopted on 27 July 2014. The article stipulates that 'no charges shall be commenced or continued before the Court against any serving AU Head of State or Government or anybody acting or any entitled to act in such capacity, or other senior state officials based on their functions, during their tenure of office'.

The initial Protocol on the Statute of the African Court of Justice and Human Rights that was adopted in $2008^{1}$ did not contain an immunity clause. The article observes that the immunity clause inserted into in the Amendment Protocol was developed in the context of the tense relationship between the $A U$ and the International Criminal Court (ICC). The AU criticises the ICC for targeting Africans given that nine out of the 10 situations under investigation by the ICC are from Africa. ${ }^{2}$ However, as discussed below, the central issue is the ICC's refusal to grant immunities to incumbent African heads of state and government and other senior officials.

The rift between the ICC and the AU - which initially was a supporter of the international court - originated when the ICC in 2009 issued an arrest warrant against a sitting head of state, President Omar Al Bashir of Sudan. Ironically, the AU has not raised objections against the cases involving the indictment of rebel leaders (four of the nine cases on Africa). These cases indeed were brought to the ICC at

1 The African Court of Justice and Human Rights was established to merge the African Court on Human and Peoples' Rights and the Court of Justice of the African Union.

2 M Caldwell 'African Union criticises International Criminal Court at member states' meeting' All Africa 19 November 2015 http://allafrica.com/stories/20151120 0495.html (accessed 2 February 2016). 
the behest of African governments, as in the case of the Democratic Republic of the Congo (DRC), Central African Republic (CAR), Uganda and Mali. ${ }^{3}$

Out of the five situations brought before the ICC by the United Nations (UN) Security Council (UNSC) and the ICC Chief Prosecutor, the AU mainly picked issue with the indictments against sitting leaders in Sudan and Kenya. Following the issuing of an arrest warrant against of Al Bashir of Sudan, the AU embarked on a fierce campaign for immunity for sitting leaders within the ICC framework. The AU contends that sitting heads of state and government should be immune from prosecution based on the need to uphold the sovereignty of states and to avoid jeopardising the legitimacy of governments and the stability of states. ${ }^{4}$

When the ICC initiated the cases against President Uhuru Kenyatta and Deputy-President William Samoei Ruto of Kenya, the condemnation of the ICC's apparent targeting of Africa grew louder. Without any formal investigation by the $A U$, it is clear that the regional body took it as a matter of principle to insist on immunity for incumbent leaders regardless of the situation. When the ICC withdrew the charges against President Kenyatta in December 2014 and terminated the case against Deputy-President Ruto in April 2016 the AU commended the ICC's decision. However, the situation has since escalated.

At the AU Summits in January and July 2016 the AU urged its Open-Ended Ministerial Committee on the ICC to develop a comprehensive strategy on a collective withdrawal from the ICC. ${ }^{5}$ In January 2017 the AU adopted an ICC withdrawal strategy which encouraged AU member states to withdraw from the Rome Statute. ${ }^{6}$ The AU Assembly also praised earlier attempts in 2016 by Burundi, South Africa and The Gambia to withdraw from the ICC. ${ }^{7}$

The AU's withdrawal strategy is yet to be revisited by the $A U$ Assembly, but Burundi, serving as the interim Chair of the AU's OpenEnded Ministerial Committee on the ICC, $^{8}$ in January 2018 led a

3 ICC 'Situations under investigation' https://www.icc-cpi.int/pages/situations.aspx (accessed 19 August 2016).

4 Coalition for the International Criminal Court 'Report on the 12th Session of the Assembly of States Parties to the Rome Statute' (2013) 6 http://www.iccnow.org/ documents/asp12_report.pdf (accessed 17 June 2016).

5 AU Assembly 'Decisions, declarations and resolution: Assembly of the Union Twenty-Sixth Ordinary Session' January 2016, Assembly/AU/Dec.588-604(XXVI), https://au.int/sites/default/files/decisions/31274-assembly_au_dec_605620_xxvii_e.pdf (accessed 20 October 2018).

$6 \mathrm{AU}$ Assembly 'Decision on the International Criminal Court' January 2017 https:// au.int/sites/default/files/decisions/32520-sc19553_e_original_-_assembly_decision s_621-641_-_xxviii.pdf (accessed 12 October 2018).

7 After the electoral defeat of The Gambia's dictator Yahya Jammeh, the new government rolled back on the country's bid to withdraw from the ICC. South Africa's withdrawal bid was also deemed unconstitutional and nullified by the national judiciary.

8 The Committee was established to follow up on the AU's concerns about the ICC. 
campaign against the ICC. The AU Assembly condemned the ICC decision to open investigations on the situation in Burundi based on the recommendation of the Ministerial Committee on the ICC. The AU Assembly claimed that the ICC's decision was 'prejudicial to the peace process under the auspices of the East African Community, and constitutes both a violation of the sovereignty of Burundi and is a move aimed at destabilising that country'. ${ }^{9}$

Since 2014, the AU had already moved to ensure that the African Court respects the immunity of sitting leaders and senior officials on the continent through the Amendment Protocol. ${ }^{10}$ Although the Amendment Protocol has not yet entered into force, the immunity clause reflects the stance of the $A U$ on matters of justice and accountability.

However, there has been a limited assessment of the ramifications of the AU's immunity principle on the efficiency of the African Court and the need for conflict resolution in Africa where the role of leaders in conflict situations is significant. Will the grant of immunity to sitting heads of state and senior government officials enable the continent to realise justice as well as advance conflict resolution on the continent?

Hence, the article explores the implications of the immunity stance on conflict resolution in Africa. The case of South Sudan is a useful case for engaging with the impact of the immunity clause on resolving conflicts and attaining justice in Africa. The Habré case further highlights some empirical lessons on the fate of justice and reconciliation in Africa.

Since December 2013 South Sudan has been embroiled in a civil war sparked by leadership tussles in the Southern Peoples' Liberation Movement (SPLM) party that led the region into independence in 2011 after a violent conflict with the Sudanese government in the north. The conflict pitted the SPLM in power led by President Salva Kiir with the SPLM in opposition led by the sacked Vice-President Riek Machar. Several elites have since broken away from the Kiir and Machar camps to form their own armed groups. Although the South Sudanese conflict has a complex dimension, reports on the conflict have consistently indicted the country's leaders as the commanders and beneficiaries of the war crimes and crimes against humanity. The article observes that the historical lack of accountability for war crimes and crimes against humanity in the region provides an ambient for the warring parties to persist with impunity in warfare.

Several peace talks have taken place and agreements reached, including the Agreement on the Resolution of the Conflict in the

9 AU Assembly 'Decision on the International Criminal Court' January 2018, https:// au.int/sites/default/files/decisions/33908-assembly_decisions_665_-_689_e.pdf (accessed 12 October 2018).

10 The AU decision of January 2018 also called for an 'advisory opinion from the International Court of Justice on the question of immunities of a Head of State and Government and other senior officials'. 
Republic of South Sudan (ARCSS) on 25 August 2015, a deal reached under the coordination of the Intergovernmental Authority on Development (IGAD). ${ }^{11}$ The ARCSS was violated in July 2016 following the outbreak of violence between the warring factions three months after the formation of a transitional government. Despite the signing of new agreements between June and October 2018, reports of violations persist and the leaders of the warring factions often depict themselves as unconcerned about the consequences of the violations of the peace agreements. Thus, any real effort at pursuing accountability and bringing an end to the violence in South Sudan has to engage with the role of the warring leaders who now take up leadership positions in the government.

There remains limited effort by IGAD mediators to highlight the accountability of the leaders for the human rights abuses in South Sudan. The Hybrid Court for South Sudan (HCSS) is meant to be operationalised by the AU in line with the ARCSS agreement, and there is no provision for immunity against prosecution. However, section 4 of this article argues that based on the current AU stance on immunity for sitting leaders, the continental body will face difficulties in prosecuting the leaders of the warring factions that will make up any new government in South Sudan after some stability has been attained.

As such, the game for warring leaders is to be co-opted into leadership through the peace process, and they are under no pressure to desist from human rights violations since they derive legitimacy and a seat at the negotiation table through violence. ${ }^{12}$ As discussed further in section 4.1, the immunity clause for sitting heads of state and senior leaders also fails to address concerns across the African continent where a number of sitting heads of state prefer to 'sit tight' in office and are suspected of having committed gross human rights violations. The successful prosecution of former Chadian President Hissène Habré by an AU-mandated national court in Senegal created renewed momentum around the functioning and efficiency of criminal prosecution against a former head of state in Africa. However, the successful prosecution of Habré was possible because he no longer enjoyed political support and lacked international allies. In conflict settings that require deterrence measures to avoid impunity and state oppression, waiting for leaders in Africa to lose political power, which is encouraged by the AU immunity clause, does not bode well for

11 While sub-regional bodies are independent bodies, they are also expected to align their policies to that of the AU in line with art 4(b) of the Protocol on relations between the $A U$ and regional economic communities (RECs). The operations of the RECs fall within the 'principle of subsidiarity', which requires RECs/RMs to respond to challenges in their sub-region.

12 D Majak 'Taming the dominant gun class in South Sudan' https://africacenter.org/ spotlight/taming-the-dominant-gun-class-in-south-sudan/ (accessed 12 October 2018). 
conflict resolution and justice on the continent, especially in the case of South Sudan.

The next section provides a contextual framework for engaging with the issues discussed in the article.

\section{A constructivist framework for justice as a tool for conflict resolution}

The theoretical framework of constructivism - which highlights the influence of prevailing ideas - provides a useful framework for understanding how normative values come about, including the idea of transitional justice and the $A U$ stance on immunity for sitting leaders in Africa. The prominent feature of constructivism is its divergence from dominant theories - neo-realism and neo-liberalism. Constructivism holds that the significant influence in international relations is social consciousness or prevailing ideas in the system as opposed to material elements. ${ }^{13}$

In this regard the international system is founded on the intersubjective ideas that are shared among people. This includes the institutionalised ideas that are expressed as practices and identities. ${ }^{14}$ Wendt in his article illustrates the influence of ideas by arguing that '[500] British nuclear weapons are less threatening to the United States than five North Korean nuclear weapons'. ${ }^{15}$ In this claim, the US perceives Britain as an ally while it views North Korea as an enemy capable of acting aggressively. If it were merely about material capability, the US would be threatened more by Britain than by North Korea. Hence, the concerns relating to security in the world order, for instance, do not merely involve a consideration of the resources, weapons and other material elements of other states as espoused by neo-realists. Rather, it concerns ideas that prevail in the international system based on the historical and behavioural relationships of states. This condition implies that if the ideas in international relations change, the relationships in the international relations also change.

Relations in the international order have over the years led to the formation and changes of ideas in the international system. For instance, the idea of sacrosanct and inviolable sovereignty have over the years shifted to sovereignty as responsibility, ${ }^{16}$ as expressed in the Responsibility to Protect (R2P) doctrine, which was endorsed by the

13 R Jackson \& G Sorensen 'Social constructivism' in R Jackson \& G Sorensen (eds) Introduction to international relations: Theories and approaches (2006) 162.

14 JW Legro Rethinking the world: Great power strategies and international order (2005) 6.

15 A Wendt 'Anarchy is what states make of it: The social construction of power politics' (1992) 46 International Organization 391.

16 MK Cusimano Beyond sovereignty: Issues for a global agenda (2000). 
2005 UN World Summit Outcome Document. ${ }^{17}$ The next section engages with some ideas that have over the years been constructed in international relations, especially in terms of international justice.

\subsection{International laws on justice}

Parallel to the paradigm shift from the idea of sacrosanct sovereignty to sovereignty as responsibility, the notion of justice also has shifted from a national confine to the greater role of the international community in seeking justice, especially in conflict areas. This development is aptly captured by the 2004 UN Report of the HighLevel Panel on Threats, Challenges and Change which surmises that any threat to a state and to human life en masse constitutes a threat to international security. One of the primary normative and institutional frameworks for international justice is international humanitarian law.

International humanitarian law serves as an international legal framework to limit the effect of armed conflict so as to mitigate suffering. It is founded on two international conventions, namely, the Hague Convention (1907) that restricts the means and methods of warfare, and the four Geneva Conventions (1949) that provide for the protection of certain categories of vulnerable persons: those wounded and sick in armed forces in the field; the wounded, sick and shipwrecked members of armed forces at sea; prisoners of war; and civilians not belonging to the armed forces, including non-nationals and refugees. ${ }^{18}$ These international laws are applicable to all states and all actors in situations of armed conflict. ${ }^{19}$

Pursuant to this law and in recognition of the limitations of domestic courts, the UNSC established ad hoc international tribunals, such as those in the former Yugoslavia, Rwanda and Sierra Leone, to address the legal responsibilities of individuals in relation to war crimes, genocide and crimes against humanity. In 2002 the ICC was established by the Rome Statute as a permanent international court

17 The R2P entails that the broader international community bears the responsibility to intervene in the internal affairs of member states when a particular state in question fails or is unwilling to protect civilians in line with chs VI and VII of the UN Charter. Thus, the classical inviolable right to sovereignty - an 'exclusive and final jurisdiction over territory, as well as resources and populations that lie within the territory' as endorsed by the 1648 Treaty of Westphalia - have become diluted with conditions which states need to fulfil to avoid external interference. UN 'Overview of international humanitarian law' (2016) http://www.gsdrc.org/topicguides/international-legal-frameworks-for-humanitarian-action/concepts/ overview-of-international-humanitarian-law/ (accessed 20 June 2016).

18 International Justice Resource Centre 'International humanitarian law' (2016) http://www.ijrcenter.org/international-humanitarian-law/ (accessed 20 June 2016).

19 Another pertinent law is international human rights law, which is founded on the Universal Declaration of Human Rights that was adopted by the UN on 10 December 1948. The Universal Declaration, together with other relevant international instruments, stipulates the basic civil, political, economic, social and cultural rights that all human beings should enjoy. 
with a mandate to prosecute those responsible for international crimes. ${ }^{20}$

The UN also has advanced the notion of transitional justice, which serves as the 'the full set of processes and mechanisms associated with a society's attempts to come to terms with a legacy of large-scale past abuse, in order to secure accountability, serve justice and achieve reconciliation'. 21 Transitional justice involves a range of judicial and non-judicial mechanisms including individual prosecutions, reparations, truth seeking and institutional reform. In attaining justice, international courts, such as the ICC and the African Court, are meant to complement national judicial institutions. They serve as last resorts to justice in light of the inability or unwillingness of domestic courts to prosecute cases genuinely, especially in states in crises and fragile states. Hybrid courts such as the anticipated Hybrid Court for South Sudan are meant to comprise both international and national judicial officials to ensure that the international community supports weak national judicial systems in pursuing justice. The South Sudan Hybrid Court is meant to be established by the AU with the cooperation of the government. These mechanisms serve to prevent impunity and to ensure the accountability of domestic elites that often operate within the confines and protection of the sovereignty of states.

Although transitional justice often takes place after some stability has been restored in conflict states, the idea of international justice is meant to deter would-be perpetrators of crimes. The idea also serves to nudge conflict parties to avoid human rights violations and pursue a timely conflict resolution, which entails addressing the causes of conflict to ensure lasting peace and security.

\subsection{Construction of the immunity clause in Africa}

The idea of common goals and values dominates policy and interstate discourses of African intergovernmental organisations. While there are divergences in the values and priorities in Africa, the idea of pan-African unity, destiny and cooperation has remained a motivating factor for inter-African cooperation through continental and regional organisations.

It is within the constructivist idea of common identity and unity for a common cause that the $\mathrm{AU}$, which is made up of African governments, advances the immunity clause for sitting leaders and senior government officials in Africa. While arguing against the ICC's alleged witch-hunt of African states, the AU cites the need for stability

20 The International Court of Justice was also established by ch XIV of the Charter of the United Nations to safeguard international law, especially that pertaining to states.

21 United Nations Secretary-General 'The rule of law and transitional justice in conflict and post-conflict societies' (2004) UN Doc S/2004/616 (23 August 2004), http://www.un.org/en/ga/search/view_doc.asp?symbol=S/2004/616 (accessed 20 October 2018). 
in African states, which could be jeopardised by the trial of sitting heads of state and senior officials. ${ }^{22}$ By extension, the collective decision of $\mathrm{AU}$ leaders for immunity influences the behaviour of governments and leaders. AU member states such as South Africa, for instance, refused to hand President Omar Bashir over to the ICC when he visited the country for the 2015 AU Summit. Besides South Africa's particular national considerations, the decision was based on the collective decision and idea of immunity for sitting leaders as constructed by the AU. Reports also note that South Africa had signed a memorandum of understanding with the AU that it would not arrest Bashir. The initial withdrawal by The Gambia, South Africa and Burundi from the ICC in 2016 was undertaken in the knowledge that the AU would support such a move. Indeed, while agreeing to the $A U$ 's collective withdrawal strategy, the AU Assembly praised these countries even though South Africa and The Gambia have abolished their withdrawal decision. To avoid possible confusion on the continent, the $\mathrm{AU}$ included the immunity of sitting leaders in article 46Abis of the Amendment Protocol.

Although the Hybrid Court for South Sudan in writing does not provide for the immunity of government officials, South Sudanese officials are conscious of the AU's traditional stance on immunity. This stance includes the precedent set by the $A U$ in terms of the rejection of trials against incumbent leaders and senior government officials. As such, the calculations of the warring parties of South Sudan rightfully may be influenced by the AU's immunity perspective, as discussed below.

\section{Human rights violations in South Sudan}

In order to understand the imperative for justice in South Sudan, it is important to understand the context of human rights violations in the country, and the responsibility of warring leaders, who eventually will make up the new government. South Sudan on 13 December 2013 plunged into civil war after three years of independence. The conflict pitted the Nuer and Dinka groups against one another as former VicePresident Riek Machar from Nuer faced off against his rival, President Salva Kiir from the Dinka tribe. Other warring factions have broken away from the government and opposition to form their own armed groups, and to canvass for inclusion in the peace process. ${ }^{23}$ Despite numerous peace talks, the warring leaders have led large-scale military operations that have affected civilians. A report by the Human Rights Council in March 2016 indicated that thousands of people had been killed in South Sudan with over two million people displaced from

22 AU Assembly (n 9).

23 'Why another power-sharing deal in South Sudan has collapsed' PSC Report 8 June 2018 https://issafrica.org/pscreport/situation-analysis/why-another-power-sharing -deal-in-south-sudan-has-collapsed (accessed 10 October 2018). 
their homes. ${ }^{24}$ The violence includes various attacks against the UN Mission in South Sudan (UNMISS) personnel and facilities as well as aid workers.

The humanitarian crisis led the AU Peace and Security Council (PSC) at its 411th meeting on 30 December 2013 to establish the Commission of Inquiry on South Sudan (Commission) 'to investigate the human rights violations and other abuses committed during the armed conflict in South Sudan and to make recommendations on the best ways and means to ensure accountability, reconciliation and healing among all South Sudanese communities' ${ }^{25}$ The report of the Commission revealed that the warring parties had murdered, tortured, raped and committed other sexual and gender-based crimes against civilians. ${ }^{26}$ These include the crimes of conscripting children and looting and destroying civilian property.

A report by the UN Office of the High Commissioner for Human Rights (OHCHR) gave searing accounts of how civilians suspected of supporting the opposition were killed by being burnt alive, suffocated in containers, shot, hanged from trees or cut to pieces, and 'several women said they were raped when they left UN protected camps to search for food; others were abducted and held in sexual slavery as "wives" for soldiers in barracks'. ${ }^{27}$ These reports, which are mainly overviews of the human rights violations, are clear indications of war crimes and crimes against humanity in violation of international humanitarian law.

\subsection{Liability of domestic leaders}

A study reveals that, when asked about the cause of the 2013 conflict,

the majority of the respondents cited a struggle over SPLM leadership (52\%), an attempted coup (21\%) and a clash between members of the army $(17 \%)$ as the main causes of the conflict ... a clear majority identifies the main problems as being at the leadership level (67\%). ${ }^{28}$

The findings of the AU Commission of Inquiry on South Sudan corroborates this conclusion by noting that the conflict centres upon the leadership figures of South Sudan, particularly within the SPLM.

24 Human Rights Council 'Thirty-first session: Annual report of the United Nations High Commissioner for Human Rights and reports of the Office of the High Commissioner and the Secretary-General' (2016) http://www.ohchr.org/EN/ HRBodies/HRC/RegularSessions/Session31/Documents/A-HRC-31-49_en.doc (accessed 20 June 2016).

25 African Union Final Report of African Union Commission of Inquiry on South Sudan (2015) 8.

26 The report insists that accountability is key to a durable solution to the South Sudanese security context. This contributed to the inclusion of the Hybrid Court for South Sudan (HCSS) within the ARCSS that was signed in August 2015.

27 OHCHR 'South Sudan: UN report contains "searing" account of killings, rapes and destruction' (2016) http://www.ohchr.org/EN/NewsEvents/Pages/DisplayNews. aspx?NewsID=17207 (accessed 1 September 2016).

28 DK Deng \& R Willems Expanding the reach of justice and accountability in South Sudan: Intersections of truth, justice and reconciliation in South Sudan (2016) 6. 
The Commission's report revealed that 'Riek [Machar] wanted to be the Chairman, Rebecca Nyandeng wanted to be the Chairperson, Pagan [Amum] wanted to be Chairman and Salva [Kiir] wanted to continue. That was the problem.'29

Prior to independence significant differences in the leadership, especially between President Kiir and his Vice-President, were overlooked for the sake of unity. The division led to the stripping of executive powers from Machar in May 2013 and his eventual dismissal on 23 July 2013 along with most of the Cabinet (with the exception of four Ministers) and the suspension of the SPLM Secretary-General, Pagan Amum, for alleged corruption.

Markedly, during the meeting of the SPLM's National Liberation Council in Juba in December 2013, fighting broke out between soldiers loyal to the President and those in support of Machar. The fighting soon spread to the general population in other regions. The report of UNMISS notes that South Sudan's military and National Security Service (NSS), including the opposition forces, 'operate in a space above the law and with virtual impunity'. ${ }^{30}$ The victims of the power tussle are people in villages that have little or no say on who holds leadership positions in the SPLM. ${ }^{31}$

Kiir and Machar, the main rivals in the conflict, have a significant responsibility regarding the human rights violations. However, since most of the peace process entails them serving as top leaders in South Sudan, questions are raised as to how to hold them accountable. Beyond the Kiir and Machar divide, various other leaders have since broken away from Kiir and Machar's faction to form their own armed groups. Irrespective of their claims to forming armed movements, the creation of new movements partly occurred because their participation in the peace process and their chances of gaining senior leadership positions in a new government depend on the extent of the threat posed by their groups.

For instance, Lieutenant-General Thomas Cirillo Swaka, a former deputy chief of general staff for logistics, in February 2017 left the Kirr government to form the National Salvation Front (NAS). Lam Akol, a former Minister of Agriculture, also left the government to form the National Democratic Movement in 2016. There is also Peter Gatdet's South Sudan United Movement (SSUM) of 2016 which splintered from the Federal Democratic Party/South Sudan Army Forces (FDP/ SSAF). The FDP/SSAF, currently led by Gabriel Changson, had also

$29 \mathrm{AU}(\mathrm{n}$ 25) 24-26.

30 FIDH 'Addressing the human rights situation and the need for accountability for atrocities committed in South Sudan' https://www.fidh.org/en/internationaladvocacy/united-nations/addressing-the-human-rights-situation-and-the-need-foraccountability (accessed 30 August 2016).

31 MJ Kur 'Major African transitional justice mechanisms: Lessons for South Sudanese government and civil society' (2016) https://paanluelwel.com/2016/07/08/majorafrican-transitional-justice-mechanisms-lessons-for-south-sudanese-governmentand-civil-society/ (accessed 7 September 2016). 
defected from Machar's group in mid-2015. The most recent armed group is that of Paul Malong who formed the South Sudan United Front (SSUF) on 9 April 2018. Malong was the former Chief of General Staff of the army who was sacked in May 2017 and placed under house arrest until November 2017.

Other examples include the South Sudan Federal Democratic Party (SSFDP) of 2015; the South Sudanese Patriotic Army (SSPA) of 2015; and the South Sudan National Movement for Change of 2017, among many others. Some of these groups formed the South Sudan Opposition Alliance (SSOA) to work together during the peace process, but the strength of the armed groups differs and reaching agreement within the alliance remains a major concern.

Due to the proliferation of armed groups, the recent Khartoum peace deal led to the creation of additional vice-presidential positions. $^{32}$ The initial deal of 2015 contained a First Vice-President position and a Vice-President position. ${ }^{33}$ The current deal requires five vice-president positions including the First Vice-President and four other vice-president positions. This arrangement entails three additional vice-presidential positions to satisfy the interests of the warring leaders. The Council of Ministers has also increased from 30 as provided by the initial ARCSS to 35 in the new deal. The number of the members of the national legislative assembly has also increased from 400 to 550 in the new deal. The need for inclusivity is vital. However, violence secured those governing positions for the warring leaders. In line with the AU's stance on immunity, President Kiir and First Vice-President Machar and the other vice-presidents could be shielded from prosecution while in office. Other elites that make up the executive and the national assembly also could raise their role as senior leaders in the government.

Given that violence remains the ticket to sustained leadership positions, a genuine attempt at addressing the crisis requires addressing the lack of accountability in the country regardless of their positions in the current governing arrangement. Apart from the call by human rights activists for accountability, South Sudanese also have been vocal in requesting justice for the crimes in the region, as discussed in the next section.

\subsection{Quest for justice in South Sudan}

Several research findings observe that the indiscriminate violence in South Sudan is the result of a culture of impunity and lack of accountability in the region. ${ }^{34}$ For over 40 years of civil war in the

32 Revitalised ARCSS 28 August 2018, https://www.dropbox.com/s/tss2y6pelt3snlx/ ARCSS\%202018\%20Initialled.pdf?dl=0 (accessed 28 October 2018).

33 Agreement on the Resolution of the Conflict in the Republic of South Sudan (ARCSS) 2015, https://drive.google.com/file/d/0B5FAwdVtt-gCelBQZVAxbjhUc1 FmSHo3VnNaT09Ldm1GNEhz/view (accessed 28 October 2018). 
region, South Sudan has not witnessed a history of comprehensive justice and accountability for war crimes and crimes against humanity. ${ }^{35}$ Although much of the conflict faced by South Sudan before 2011 was between the SPLM army (SPLM/A) and the Khartoum government in the north, there has been a significant internal communal and leadership conflict in South Sudan that did not receive adequate attention due to the predominant description of the conflict as something happening between the north and south of the Sudan. ${ }^{36}$

The Comprehensive Peace Agreement (CPA) that ended the civil war with Sudan in 2005 granted amnesty to the conflicting parties, thereby shelving the question of the accountability of the actors on both sides of the conflict. In Southern Sudan leaders of the warring factions were rewarded with top positions in government institutions, thereby creating the impression that violence pays and the bigger your gun, the better prospect of prominent recognition you will have. The historical negligence displayed towards the gross human rights abuses in the region entails that conflicting parties are unaware of or nonchalant about international justice.

After independence in 2011 already there had been sporadic outbreaks of violence in South Sudan before the outbreak of the civil war in December 2013.37 This situation highlights the consequences of lingering impunity. Since 2013 when the civil war erupted the parties to the conflict have defied at least six major ceasefire deals, including those signed in January 2014, May 2014, February 2015, August 2015, December 2017 and as recently as June 2018. Indeed, heavy fighting often is witnessed hours after the signing of a ceasefire deal. This reality indicates that another move towards amnesty in the region will perpetuate the impunity.

A study by Deng et al reveals that there is a high demand for justice and accountability in South Sudanese societies. ${ }^{38}$ A survey of 2016

35 Since the first war broke out in the South Sudanese region on 18 August 1955 due to a mutiny at Torit, Equatorial, there has never been a concrete effort at investigating war crimes in the region. In 1983 the second war broke out when the government abrogated the 1973 agreements that ended the first civil war. The 1973 agreement under President Jafaar Nimeiri had granted autonomy to the south under a federal system of government. The government in 1983 abrogated the law and dissolved the Regional Assembly, leading to the South Sudan civil war that ended in 2005 after the signing of the Comprehensive Peace Agreement of 2005. The Agreement further paved the way for the secession of South Sudan from Sudan in 2011.

$36 \mathrm{AU}(\mathrm{n} 25)$.

37 UN Security Council Report 'Chronology of events in South Sudan' (2016) http:// www.securitycouncilreport.org/chronology/south-sudan.php (accessed 20 June 2016).

38 DK Deng et al Search for a new beginning: Perceptions of truth, justice, reconciliation and healing in South Sudan (2015), http://www.undp.org/content/dam/south sudan/library/Rule\%20of\%20Law/Perception\%20Survey\%20Report\%20Transition al\%20Justice\%20Reconciliation\%20and\%20Healing\%20-.pdf (accessed 20 June 2016). 
shows that a significant number of people do not believe that amnesties can contribute to lasting peace: 'Forty-eight per cent of respondents thought that amnesties would have either a negative effect $(32 \%)$ or no effect $(16 \%)$ on prospects for peace, while 47 per cent thought that it would have a positive impact on prospects for peace. ${ }^{\prime 39}$ A study conducted by the American Bar Association Rule of Law Initiative in South Sudan in 2014 revealed that 'every person interviewed indicated that there must be accountability, at all levels, for the atrocities committed during the current crisis' ${ }^{40}$ Even though the survey was taken in the context of the ongoing conflict, the opposition to amnesty demonstrates the frustration of people about the lack of accountability and the senseless suffering of victims in the region. One study highlights the need to tame the gun class who use violence as a means to achieve their narrow interests in South Sudan. 41

Justice becomes imperative to break the cycle of violence and reverse the legacies of past human rights violations and widespread impunity. What is certain is that South Sudanese justice institutions lack capacity, institutional means and resources to satisfactorily prosecute international crimes. In addition, their independence and impartiality cannot be guaranteed.

\subsection{Inefficiencies of domestic justice in South Sudan}

A number of studies observe that South Sudan's statutory judicial systems have not proven to have the capacity to produce tangible results on issues of justice or holding perpetrators accountable. A study by the American Bar Association Rule of Law Initiative highlights the gross limitations of the justice institutions in terms of investigation, documentation and prosecution of human rights abuses. ${ }^{42}$ Willems and Deng observe: ${ }^{43}$

South Sudan's justice system has a plural justice system comprised of parallel systems of statutory courts presided over by judges and trained legal personnel and customary courts presided over by chiefs and elders. The statutory courts are structured in a single hierarchy with the Supreme Court as the highest court of law, followed by three courts of appeal, high courts in each of the ten states and magistrate courts at the county level. But those courts have not yet been established. Indeed, there are not even magistrate courts present in many of the counties.

As in South Sudan, justice remains unfulfilled for many Africans wanting accountability, reconciliation and lasting peace since the

39 Deng \& Willems (n 28) 12-14.

40 American Bar Association Rule of Law Initiative Assessment of justice, accountability and reconciliation measures in South Sudan: Final report and recommendations (2014).

41 Majak (n 12).

42 American Bar Association Rule of Law Initiative (n 40).

43 R Willems \& D Deng Justice and conflict in South Sudan: Observations from a pilot survey' $^{\prime}$ (2015) 7. 
early 1990s due to weak justice institutions. ${ }^{44}$ This situation often has encouraged aggrieved actors to use force and extrajudicial approaches to realise their ends. The limitations of the internal judicial system of South Sudan have already contributed to making communities 'carry out violent attacks against neighbouring communities in retribution for harm that was done to them and as a deterrent against future attacks'. ${ }^{45}$ In a statement to the AU PSC, President Mogae noted that 'if the legacy of conflict and impunity is to be finally broken in our continent's newest state, we must also act and not disappoint a new generation of South Sudanese'. ${ }^{46}$

President Kiir was quoted as saying: 'I will not protect anybody, and I have instructed the investigation committee ... to see that all these people who committed crimes must be punished, if need be, with death. ${ }^{47}$ However, the government has not made a comprehensive effort to hold people accountable since the war began in 2013. On 30 August 2016 the government through the military court made a token attempt to convict 60 soldiers for murdering civilians and looting during the fighting in Juba in July $2016 .{ }^{48}$ This attempt, however, does not account for the systematic killing of civilians. The opposition leader, Machar, had also promised to investigate a massacre in Bentiu town, Unity state, by his rebel forces in April 2014, but no findings had been made public.

Moreover, although the leaders seem to suggest that field soldiers are culpable for crimes against humanity during the war, it is the warring leaders that have a central role and responsibility for the war crimes. Notably, criminal accountability involves different aspects of accountability and different levels of perpetrators. Leaders and senior military officers of warring parties may be responsible for human rights violations by subordinates. As discussed earlier, a number of reports hold leadership figures accountable for being the primary actors that orchestrate and lead the perpetration of war crimes and crimes against humanity.

Cognisant of the limitations of national courts, chapter 5 of the ARCISS provides for the establishment of the Hybrid Court for South Sudan to try and to prosecute war crimes, genocide and crimes against humanity. The question then is whether the HCSS can lead to effective justice. The following section discusses the responsibilities of

44 International Centre for Transitional Justice (ICTJ) Conflict and transitional justice in Africa (2009).

45 Willems \& Deng (n 43) 2.

46 D Booth 'South Sudan, Africa, and the challenge of peacemaking' (2016) http:// www.state.gov/p/af/rls/rm/2016/252466.htm (accessed 12 August 2016).

47 http://www.aa.com.tr/en/rss/329575--kiir-vows-to-try-people-involved-in-s-sudancrimes (accessed 12 August 2016).

48 'Court convicts 60 South Sudanese soldiers for murder' Sudan Tribune 30 August 2016 http://www.sudantribune.com/spip.php?article60080 (accessed 12 August 2016). 
the HCSS and how the AU's immunity principle thwarts the deterrent capacity of the HCSS.

\section{Hybrid court for South Sudan and the African Union}

After the ARCSS of 2015 stalled following the outbreak of violence in July 2016, IGAD led a high-level revitalisation forum to revive the ARCSS. The new agreements were mainly around ceasefire as well as governance and security arrangements. The discussions were held in the knowledge that institutions such as the HCSS, the Commission for Truth, Reconciliation and Healing (CTRH) and the Compensation and Reparation Authority (CRA) would remain in the revised version of the ARCSS of 2015. Chapter 5 of the ARCSS provides for the establishment of an independent hybrid judicial body known as the Hybrid Court for South Sudan. Chapter 5(6.2.2) notes that the HCSS shall be independent and distinct from the national judiciary of South Sudan and the Court shall carry out its own investigations with primacy over any national courts in South Sudan. ${ }^{49}$

To ensure that influential domestic actors do not influence the outcome of the Court the agreement stipulates that the AU holds the primary responsibility for the development of the framework for the HCSS. Chapter 5(6.1.1) highlights this by noting that the Hybrid Court is to 'be established by the African Union Commission to investigate and prosecute individuals bearing the responsibility for violations of international law and/or applicable South Sudanese law, committed from 15 December 2013 through the end of the Transitional Period'. The HCSS is to be comprised of some South Sudanese and a majority of African (non-South Sudanese) judges, lawyers and administrative staff.

The Court will be the first to be established and administered by the AU. The AU Commission (AUC) is to provide relevant information on the location, funding, enforcement, jurisprudence, number of and composition of judges, and privileges and immunities of Court personnel. In this regard, the AU effort is critical for the attainment of justice in South Sudan and, by extension, to deter warring parties from committing war crimes.

The HCSS is intended to try every person regardless of position. As indicated in chapter 5(6.5.1) of the revised ARCSS, 'a person who planned, instigated, ordered, committed, aided and abetted, conspired or participated in a joint criminal enterprise in the planning, preparation or execution of a crime ... shall be individually responsible for the crime'. Chapter 5(6.5.4) further stipulates that 'the HCSS shall

49 The HCSS is expected to 'independently promote the common objective of facilitating truth, reconciliation and healing, compensation and reparation in South Sudan' along with two other institutions, namely, the Commission for Truth, Reconciliation and Healing (CTRH) and the Compensation and Reparation Authority (CRA). 
not be impeded or constrained by any statutes of limitations or the granting of pardons, immunities or amnesties'. Chapter 5(6.5.5) further provides that 'no one shall be exempted from criminal responsibility on account of their official capacity as a government official, an elected official or claiming the defence of superior orders'.

Although the agreement provides for the trial of every person who is worth prosecuting, it is doubtful that the AU will seek to try the sitting leaders and senior government officials of South Sudan, as observed in the previous section.

\subsection{Implications of the African Union's immunity principle for conflict resolution}

As argued earlier the AU over time has developed a principle of immunity for sitting heads of states and senior government officials. The AU's immunity principle is at the heart of the well-known conflict between the $A U$ and the ICC, a conflict that has resulted in the $A U$ exploring options for the collective withdrawal of African states from the ICC. This immunity clause has been included in article 46Abis of the Amendment Protocol, which provides that sitting heads of state and senior government officials will not face trial by the African Court. The AU has ardently argued in favour of the immunity principle in many international forums.

Thus, even if the AU intends to prosecute the leaders of South Sudan, such efforts will go against the organisation's insistence that the prosecution of sitting leaders and senior government officials is detrimental to sovereignty and the stability of African states. ${ }^{50}$ This principle, which remains a topical issue on the continent, will cause affected groups to consider the AU 'hypocritical' - at least - if it should go ahead and try incumbent leaders and senior government officials in South Sudan.

A strategy paper emanating from a conference on truth, justice and reconciliation in South Sudan in August 2014 recommended that any transitional government that will be created should be bound through the peace agreement to 'ratify the Rome Statute, and to commit to doing so in any peace agreement that comes from the IGAD peace talks'. ${ }^{51}$ The intention is to provide the ICC with the opportunity to intervene if the leaders attempt to undermine the effort of the HCSS. However, the African mediators did not consider any role for the ICC on the matter in view of the differences and fraught relations between the organisations. The African mediators were comfortable with the AU Commission - not the UN or another international institution having jurisdiction over the justice outcomes. This decision is

50 Coalition for the International Criminal Court (n 4).

51 'Transitional justice strategy for South Sudan' Strategy paper, Conference on transitional justice in South Sudan entitled 'Towards a new beginning' (2014) 2. 
particularly important to protect the value interests of African actors, especially as it pertains to the nature of justice.

In this regard leaders of the warring factions in South Sudan are not ignorant of this value held in the $\mathrm{AU}$ that is charged with establishing the HCSS. The new deal gave leaders of the warring factions leadership and senior positions in the transitional government as well as opportunities for future leadership positions in a stable South Sudan. Hence, the AU's immunity principle does little to deter the South Sudanese parties from continuing the war as they deem fit since those included in leadership positions are the warring leaders. Holding leadership positions, the AU will be in a difficult position if it attempts to try these persons.

It should be noted that the AU's immunity principle is not meant to prevent any future trial or prosecution of incumbent leaders and senior government officials provided they no longer are in power. However, the penchant of some regimes to hold on to power in Africa entails that justice remains a mirage for many victims of crimes committed by incumbent regimes. Notably, out of the 33 countries with term limits in Africa, 12 countries have sought to amend their constitutions to extend or remove these limits. ${ }^{52}$ The recent trend in the DRC, Rwanda, Burundi, Uganda and Benin is evidence of the proclivity of leaders to remain firmly in office. Disturbingly, those countries that have experienced extensions in term limits are also facing human rights challenges. The stance of the $A U$ thus creates a platform for leaders to remain in power, to avoid probes or abdicate powers only to their allies. In the East African region in which South Sudan is situated there is a strong trend for leaders to remain in power.

Without attempting to foretell the future of South Sudan, it is possible to foresee that the current leaders do all they can to remain in power for a long time. During this time, vital evidence could be lost and a possible resurgence of conflict could detract attention from issues of justice. The South Sudanese agreement does not entail that the leaders of the transitional government are not to run for the leadership in post-transition South Sudan as was the case in Madagascar. Madagascar underwent a political crisis in 2009 when Andy Rajoelina took control from President Marc Ravalomanana with the support of the military and opposition parties. The movement was regarded by the international community as a coup d'état.

The international community advanced an election in 2013 without the candidacy of Ravalomanana and Rajoelina who were the key divisive figures in the country. The 2013 elections led to the election of Hery Rajaonarimampianina as President. Although some political crises remain in the region, the elections provided an avenue for the

52 'Can the AU deal with amendments to term limits' IPSS 21 September 2015 http:/ /www.ipss-addis.org/new-ipss/news-events/can_the_au_deal_with_amendments_ to_term_limits-_/ (accessed 21 July 2016). 
country to explore stability through a new leadership, thereby checking the powers of the previous leaders involved in the upheavals. Even though the crisis in South Sudan differs, the continued role of the protagonists of war in the future of South Sudan's threatens the attainment of a lasting peace and effective justice.

Will the leaders facilitate the functioning of the HCSS? The transitional government is expected to enact legislation that will formalise the AU-led HCSS into law in South Sudan. Although the ARCSS is silent on the role of the transitional government in the HCSS, chapter 5(1.2) clearly states that the transitional government would define the mandate and jurisdiction of the three institutions including, but not limited to, their establishment and funding, actors, and defined processes for public participation in the selection of their respective members. This position entails that the transitional government will play a crucial role in initiating 'legislation for the establishment of the transitional justice institutions' in line with chapter 5(1.1). Chapter 5(1.5) expects the transitional government to cooperate with the $\mathrm{AU}$ and the international community in operationalising the Court.

This gives the transitional government some leverage in influencing the establishment and mandate of the HCSS from the outset. The cooperation of the transitional government, however, is subject to question. Notably, after the formation of the transitional government, a news item appeared in the New York Times, allegedly written by Kiir and Machar. The piece holds that South Sudan requires merely truth telling and not trials: ${ }^{53}$

We intend to create a national truth and reconciliation commission modelled on those of South Africa and Northern Ireland. This commission would have wide-ranging powers to investigate and interview the people of South Sudan - from the poorest farmer to the most powerful politician to compile a true account of events during the war. Those who tell the truth about what they saw or did would be granted amnesty from prosecution - even if they did not express remorse.

In contrast to reconciliation, disciplinary justice - even if delivered under international law - would destabilise efforts to unite our nation by keeping alive anger and hatred among the people of South Sudan ... That is why we call on the international community, and the United States and Britain in particular, to reconsider one element of the peace agreement to which they are co-signatories: support for a planned international tribunal, the Hybrid Court for South Sudan. We call on them instead to commit to global backing for a mediated peace, truth and reconciliation process.

Regardless of the legitimacy of the piece, the item highlights the disposition of the leaders to the question of justice in South Sudan. In this regard it is debatable how the transitional government would

53 S Kiir \& R Machar 'South Sudan needs truth, not trials' New York Times 7 June 2016 http://www.nytimes.com/2016/06/08/opinion/south-sudan-needs-truthnot-trials.html?_r=0 (accessed 1 August 2016). 
work with the AU to facilitate the establishment of the Court. Keppler notes that

after leading South Sudan into a two-year nightmare, its leaders Salva Kiir and Riek Machar now want to shield themselves and anyone else implicated in wartime atrocities from justice ... It is obvious why these leaders want to avoid trials - they were commanders-in-chief of forces implicated in grave crimes ... during the country's bloody civil war. ${ }^{54}$

During the recent peace process there has been less discussion of the role of the HCSS. While truth telling is crucial to the process, it is not an alternative for justice. The claim that justice will impede peace is rather untrue given the experiences in Sierra Leone, Chile, Chad and the former Yugoslavia which show that criminal trials do not undermine peace; rather they foster reconciliation.

October 2016 marked the sixth-month deadline for the finalisation of the memorandum of understanding, the mandate and jurisdiction of the HCSS in line with the ARCSS of 2015. Dating the establishment of the transitional government back to April 2016 when Machar returned to Juba and was made the First Vice-President, the mandate and jurisdiction of the HCSS should have been finalised in October 2016 and the operationalisation of the Court should have been in April 2017. The AU and South Sudan have signed a memorandum of understanding ${ }^{55}$ to operationalise the HCSS, but it is not yet functional and the ongoing instability has created uncertainty around it. Moreover, IGAD mediators have not prioritised the deterrence capacity of the HCSS. The revitalised ARCSS does not contain a timeline of action on the HCSS. Even during the recent South Sudan peace process, IGAD argued against punitive measures on the warring elites stating that they will be detrimental to efforts to secure a peace deal from the warring parties. ${ }^{56}$ The recent peace deal also did not contain international enforcement mechanisms as the implementation of the deal depends on the goodwill of South Sudanese elites. ${ }^{57}$

Given the disposition of the transitional government and the AU towards immunity for sitting leaders, the HCSS, when established, could end up trying and prosecuting scapegoats within the factions of Kiir and Machar while the top leaders go free despite their alleged

54 E Keppler 'Dispatches: Giving justice the slip in South Sudan' (2016) 1 https:// www.hrw.org/news/2016/06/08/dispatches-giving-justice-slip-south-sudan (accessed 2 September 2016).

55 AU Press Release 'African Union Commission and the Republic of South Sudan successfully conclude working session on the draft legal instruments of the hybrid court for South Sudan' https://au.int/en/pressreleases/20170814/african-unioncommission-and-republic-south-sudan-successfully-conclude (accessed 15 October 2018).

56 IGAD 'Press Release: 30th June 2018 7, Nouakchott, Mauritania', https://igad.int/ attachments/article/1878/Press\%20Release-IGAD\%20Council\%20Sideline\%20 Meet-June\%2030.pdf (accessed 15 October 2018).

57 The $\mathrm{AU}$ also insists that trials against sitting leaders jeopardise the legitimacy of governments and provide conditions for the contestation of legitimate authorities in Africa. 
involvement in ordering, instigating and planning the war crimes. It is thus argued that the possibility of effective justice in South Sudan is contingent on a policy/principle shift by the AU from immunity for sitting leaders to non-immunity on the continent.

While it is possible that justice against leaders could be attained when they no longer are in power, lessons from the Habré case highlight additional variables that complicate the quest for justice on the continent.

\subsection{Lessons from the Habré case}

The successful prosecution of former Chadian President Hissène Habré by an AU-mandated court in Senegal raises optimism about the AU's commitment to justice. ${ }^{58}$ The AU-backed court sentenced Habré on 30 May 2016 to life imprisonment for crimes against humanity during his eight-year rule (1982-1990). Habré, who fled to exile in Senegal in 1990, was found guilty of committing heinous atrocities, including 40000 politically-motivated murders and 200000 cases of torture, as revealed by the Chadian National Truth Commission in May 1992. 59 Many survivors gave searing accounts of various forms of torture and inhuman treatment they suffered. These included 'attacks against the Hadjerai ethnic group (1987), the Zaghawas (1989), and southern populations including the so-called 'Black September' in 1984; the arrest and torture of political prisoners, and the treatment of prisoners of war'. ${ }^{60}$ However, it took the victims of his rule over 17 years to attain justice.

It should be emphasised that the trial of Habré was made possible by the perseverance of Habré's victims with the support of Human Rights Watch and other human rights organisations. In January 2000 some Chadian victims brought complaints against Habré in Senegal, a decade after his deposition. Initially, the Senegalese court refused to prosecute Habré on the grounds that it did not have jurisdiction to try crimes committed in another country. The victims resorted to Belgium, given that the country has a universal law to try international crimes committed across the globe. In 2005 Belgium issued an arrest warrant for Habré after about four years of investigation.

The Senegalese government decided to arrest Habré. However, instead of extraditing him to Belgium as requested by the Belgium judiciary, the government - following a request by the $\mathrm{AU}$ in July 2006 - decided to prosecute Habré on behalf of Africa. The Senegalese Constitution was amended in 2008 to allow the

58 'Habré's trial brings momentum to African justice on the continent' Daily Mail 1 June 2016 http://www.dailymail.co.uk/wires/afp/article-3619723/Habre-trialbrings-momentum-African-justice-continent.html (accessed 10 July 2016).

59 USIP 'Truth Commission: Chad' (1990) http://www.usip.org/publications/truthcommission-chad (accessed 12 July 2016).

60 'Chad: Q \& A - The case of Hissène Habré before the Extraordinary African Chambers in Senegal' All Africa 2016 http://allafrica.com/stories/2016050400 04.html (accessed 28 October 2018). 
prosecution of war crimes and crimes against humanity in and out of Senegal. After some political wrangling and financial considerations, the AU and Senegal signed a deal to set up an Extraordinary African Chamber in August 2012 to try Habré. The Extraordinary African Court was formally inaugurated on 8 February 2013. The trial began on 20 July 2015 and ended on 11 February 2016 after the testimony of 93 witnesses had been heard.

Although the trial was considered a major step forward for justice in Africa, as noted by various media reports, it was only made possible as a result of a number of circumstances, which casts doubt on the optimism about the AU's future role in pursuing justice in Africa. Events leading to Habré's prosecution demonstrate that justice for crimes committed by incumbent leaders in Africa is achieved mainly when the leader loses political support and patronage.

Notably, the incumbent President of Chad, General Idriss Déby Itno, deposed Habré in 1990. Since 1990 Habré maintained a low profile in Senegal where he went into exile, while Déby fortified political power in Chad. When Habré was to be tried, the Chadian government provided support for the prosecution. In 2002 the government permitted the trial of Habré outside Chad. ${ }^{61}$ Chad made the largest donation of US $\$ 3743000$ out of the approximately $\$ 11$ million budgeted for the trial. Ironically, there was no consideration of the role of President Déby Itno who 'was commander-in-chief of Habré's forces during the period known as 'Black September' in 1984 when a murderous wave of repression was unleashed to bring Southern Chad back into the fold of the central government'. ${ }^{62}$ Even though the Court was free to bring charges against Déby it did not do so. ${ }^{63}$

Furthermore, Habré had already lost the support of the US and France that supported him throughout his abusive regime in the 1980s. With the support of the US, Habré had seized power in 1982 from Goukouni Oueddei, a former rebel comrade who had won elections but was considered to be pro-Libya - at a time when Libya was considered a threat to the West. The US and France supported Habré with military aid, logistical support and information. In two separate reports, ${ }^{64}$ HRW revealed how the US and France had provided support to Habré throughout his rule and ignored his

61 The Chadian government had also sentenced Habré to death in absentia for allegedly planning to overthrow the government in a 2008 rebellion, but Senegal did not repatriate Habré due to requests by the UN.

62 Chad: $Q \& A(n$ 60).

63 In addition, the chief prosecutors ordered the extradition of about five key officials of Habré's regime to Senegal but the Chadian government refused to extradite them.

64 Human Rights Watch (HRW) 'Enabling a dictator' (2016) https://www.hrw.org/ report/2016/06/28/enabling-dictator/united-states-and-chads-hissene-Habré1982-1990 (accessed 25 August 2016); HRW 'US, France backed convicted Chad dictator' (2016) https://www.hrw.org/news/2016/06/28/us-france-backed-con victed-chad-dictator (accessed 26 August 2016). 
leadership abuses and human rights violations in Chad. When the tide turned against Habré, the US and France became supporters of the trial of the dictator that they had enabled. The US government contributed US $\$ 1$ million and France contributed $€ 300000$ towards the Extraordinary Court's budget. ${ }^{65}$ This scenario shows that the fact that some cases against former leaders in Africa are tried is dependent on the political disfavour of the elite. ${ }^{66}$

In the case of South Sudan, even though IGAD has played a crucial role in the resolution of the dispute in South Sudan, a survey of the leaders in the East African region shows some disapproval to questions of international justice. Actors in the region, such as Kenya's President Uhuru and Vice-President Ruto, are strong advocates against international criminal justice for leaders and senior government officials having themselves faced attempted trials by the ICC. ${ }^{67} \mathrm{Al}$ Bashir of Sudan has been in power since 1989 with no end in sight to his leadership. The nature of politics in Ethiopia, Uganda, Eritrea and Djibouti also shows that leadership accountability and limits to leadership terms are not up for contestation. Ugandan President Yoweri Museveni has been in power for 35 years and reportedly has sent troops to back the South Sudanese government during the civil war. ${ }^{68}$ In this regard it is 'not surprising, South Sudanese parties were highly attuned to these regional dynamics, and sought political advantage at each juncture, by soliciting support from neighbouring patrons'.69

The sentencing of Habré could be regarded merely as indicative of the fact that the wheels of justice turn slowly but surely. However, the victims of Habré's cruelty had to wait for over 17 years for the exChadian leader to lose political support before securing justice. As argued earlier, the uncertainty about some leaders responsible for rights abuses losing power complicates the question of justice on the continent and in South Sudan, in particular. Kur notes that the Hybrid Court is a step in the right direction. But for it to achieve its goals and deter the warlords from initiating another conflict, it must ensure that war criminals at the highest chain of leadership never escape justice. ${ }^{70}$

\section{HRW (n 64).}

66 It is also worth noting that at the time of the AU's resolve to permit the trial of Habré, Libya's Gaddafi was a prominent actor in the AU with enormous influence on the reform and initiatives of the AU. Markedly, at the time of Habrés leadership in the 1980s, Habré and Gaddafi were practically sworn enemies. It could be assumed that Gaddafi would be a staunch advocate for the trial of Habré.

67 Committee of Intelligence and Security Services of Africa (CISSA), 13th ordinary session http://www.peaceau.org/uploads/final-5th-august-communiquy-.pdf (accessed 5 September 2016).

68 'In South Sudan, a warring elite deaf to peace' Aljazeera 8 October 2014 http:// www.aljazeera.com/news/africa/2014/10/south-sudan-war-talks-kir-machar-fami ne-201410892734144547.html (accessed 6 August 2016).

69 Booth (n 46).

$70 \operatorname{Kur}($ n 31). 
With the current stance of the $\mathrm{AU}$ and its Protocol for the African Court the victims of abuses in South Sudan most probably will have to wait for a time when the leaders are likely to lose political backing to enable the trial of those leaders who orchestrated with near impunity the ongoing war in South Sudan from 2013 to 2018. As such, the immunity clause contributes to the atmosphere of violence being perpetuated, in part, by the leaders as they know they will not stand trial until such time as they cede power. The AU has to shift from its immunity stance to a non-immunity principle to end the senseless violence and impunity in the region.

It is worth noting that key debates on the topic of immunity for sitting leaders reveal that while incumbent political actors are the main critics of the indictment of sitting heads of state and senior government officials, civil society prefers the indictment of every suspect, including sitting heads of state. These conflicting positions show the divide between African political leaders and civil society on matters of accountability. The immunity clause for incumbent leaders raises doubts over the AU's purported transition from the interests of a few state elites to the interests and rights of the African people. The immunity clause for leaders further negates article $4(h)$ of the $A U$ Constitutive Act, which espouses the AU's non-indifference to human rights abuses in member states if suspected leaders remain leading figures in the continental body and are immune from investigation and trial.

\section{Conclusion}

The article examined the AU's stance on immunity and its impact on conflict resolution in Africa. The article observes that the AU's immunity stance for sitting leaders undermines the deterrence and conflict resolution capacities of the African Court, as well as ad hoc courts such as the HCSS. Because of the immunity principle, the AUled HCSS - despite being developed without any immunity provisions - will have difficulty in upholding efforts to prosecute the warring leaders who instigated, organised and commanded the war crimes and crimes against humanity in South Sudan. This outcome is because the peace deal allows the warring leaders to hold onto their leadership positions. Based on the AU's immunity stance, these leaders could evade justice.

In view of the ongoing skirmishes, the warring leaders are rarely deterred from perpetuating the historical culture of impunity in the region because they gained power through violence which bought them a place in the peace process. The impunity of the warring factions is evident from the defiance of the numerous ceasefire deals that were mediated by IGAD between 2013 and 2018. The HCSS would be likely to focus on prosecuting scapegoats of the warring camps as token attempt at justice in the region. 
The AU's immunity clause further engenders a 'sit-tight-in' office syndrome. In the context of the AU's effort to prevent and resolve conflicts, the 'unintended' consequences of immunity for incumbent leaders entails that some leaders that are notorious for human rights abuses could be tempted to remain in power to avoid a trial, thereby engendering more grievances on the continent. In South Sudan the immunity clause for sitting leaders provides an opportunity for a calculated move by the South Sudanese leaders to pursue efforts to remain firmly in power to avoid any probe once they leave political office.

Accordingly, the case of former Chadian President Hissène Habré shows that justice - in terms of crimes committed by incumbent leaders - is only possible when a leader loses political support. However, the regional dynamics in Africa, particularly in IGAD, shows that the incumbent leaders are not willing to leave office, and the question of prolonged leadership is rarely debated. Hence, victims of war crimes in South Sudan will be forced to wait for the time when the leaders lose political support to attain justice if there is any evidence left to work on. The immunity clause thus inhibits and delays the imperative of justice and durable conflict resolution and reconciliation.

If the African Court as well as AU-initiated justice institutions such as the HCSS are to be effective in conflict resolution, the AU needs to make a strategic shift from the immunity clause to ensure the timely indictment of all accused persons regardless of position. This change would also play a key role not only in deterring others from pursuing violence but in ensuring that aggrieved persons do not resort to violence as a way of seeking justice. The resolution of the conflict in South Sudan is highly contingent upon the ability of African mediators to flag the capacity of the HCSS to hold accountable warring leaders for war crimes and crimes against humanity, among other efforts.

The removal of the immunity clause from the Amendment Protocol, and the willingness of leaders to be examined by an independent court, could enable regimes in Africa to gain more legitimacy and support from the population. Until then, other international institutions, such as the ICC and UN-mandated courts, remain a credible last resort for victims seeking justice in Africa. 